\title{
TALAROMYCES ACULEATUS FROM ACIDIC ENVIRONMENT AS A NEW FUNGAL BIOSORBENT FOR REMOVAL OF SOME REACTIVE TEXTILE DYES
}

\author{
Şuheda KATAR ${ }^{1}$, Seda EROL ${ }^{2}$, Pinar AYTAR ÇELIK ${ }^{1, ~ *, ~}$ \\ Mine ÖZDEMİ ${ }^{2}$, Ahmet ÇABUK ${ }^{1,3}$ \\ ${ }^{1}$ Graduate School of Natural and Applied Sciences, Department of Biotechnology and Biosafety, \\ Eskişehir Osmangazi University, 26480, Eskişehir, Turkey \\ ${ }^{2}$ Department of Chemical Engineering, Faculty of Engineering Eskişehir Osmangazi University, 26480, Eskişehir, Turkey \\ ${ }^{3}$ Department of Biology, Faculty of Arts and Science, Eskişehir Osmangazi University, 26480, Eskişehir, Turkey
}

\begin{abstract}
Biosorption potential of Talaromayces aculeatus AMDC-14 (KF588646) as low-cost biosorbent for different dyes (Reactive Blue 13, Reactive Blue 72, Reactive Yellow 85 and Reactive Orange 13) removal from aqueous medium was studied. Experiments were performed to determine effect of initial solution $\mathrm{pH}(1-7)$, biosorbent dose $\left(0.1-2.5 \mathrm{~g} \mathrm{~L}^{-1}\right)$, contact time (15$1440 \mathrm{~min})$, dye concentration (10-200 ppm), temperature $\left(25-40^{\circ} \mathrm{C}\right)$ onto Talaromayces aculeatus biosorption. Biosorption equilibrium data were described very well for Reactive Blue 13, Reactive Blue 72, Reactive Yellow 85 and Reactive Orange 13 by Langmuir isotherm model than Freundlich isotherm model with maximum biosorption capacities which are 32.10, 71.30, 20.67 and $31.30 \mathrm{mg} \mathrm{g}^{-1}$, respectively. Biosorption of investigated dyes fitted to kinetic model of pseudo-second-order for all dyes. Gibbs free energies $\left(\Delta \mathrm{G}^{\circ}\right)$ of biosorption processes were calculated and the results indicated that all selected dyes biosorption onto Talaromayces aculeatus AMDC-14 were spontaneous in this study. And also biosorption processes had endothermic enthalpy values except Reactive Blue 72.
\end{abstract}

Keywords: Talaromyces, Biosorption, Dye removal, Low-cost adsorbent

\section{INTRODUCTION}

Textile, plastics and paper sectors using dyestuffs to colour their products have consumed larger volumes of water generating a significant amount of coloured wastewater. Visually and undesirably, the significant contaminant in wastewater is to be recognized as colour [1,2]. The properties of high solubility of commercially dyes increase the pollution in industrial wastewater, even in trace quantities [3]. High proportion of these dyes is also toxic and carcinogenic effect on to aquatic organisms [4]. Especially, treatment of textile wastewater is difficult because the dyes may include nonresolved organic molecules and are durable to light, heat and oxidizing agents [5].

Techniques for removal of some textile dyes from waste water medium are reverse osmosis, ionexchange, chemical precipitation etc. [6]. But, the practical usages of these technics have some restrictions because of their technical or economical strains. There is a serious need for a process that will be efficient and low-cost application for the removal of contaminants from waste water. In this purpose, biosorption including uptakes of contaminants (compounds, ions, etc.) by nonliving organisms has been densely studied as an economic and efficient sustainable technology [7].

Adsorption capacities of bacterial, fungal, plant, algal cells were investigated [8, 9]. Among these organisms, fungi surviving under natural environmental conditions have been discharged from industrial biotechnological process such as brewery [10]. Because of the fact that fungi are able to tolerate, adsorb, degrade and detoxify metals or dyestuffs through various mechanisms, they have been preferred for remediation processes [11]. One of the most significant reasons of using of fungal biosorbents is cell 
wall components including glucan, chitin, mannan, proteins and other polymers possessing carboxyl, hydroxyl, phosphoryl, amino, amine and imidazole functional groups on the surface [12]. Acidic environments harbouring some fungi such as species of Talaromyces, Penicillium, Scytalidium, Bahusakala, Phoma, and Heteroconium genera have harsh conditions [13]. In addition to contribution to biological diversity data, the investigating of these fungal strains to degrade, remediate, transform pollutants is an important environmental technology with bioaugmentation, bioaccumulation and biosorption strategies. For this purpose, Talaromyces sp has also been used for industrial and environmental biotechnology studies [14].

The TaIaromyces sp. could produce a number of commercial enzymes including cellulases, amylases and chitinases $[15,16]$ and it represents a fungal biomass potential source for use in biosorptive technology. These organisms exhibiting tolerance to strong acidic conditions have important potential for use in applications of biotechnology, including acidic textile dye wastewater decolorization $[3,17$ 19].

There are similar adsorption (especially metal) studies by Talaromyces sp. in the literature. Indeed, because this fungus is known to show tolerance to harsh environments, it can be investigated for various biotechnological applications. Therefore, such simple bioremediation strategies can increase the detoxification and degradation or adsorption of these polluted areas through the effective microorganisms. At the study of Romero et al., T. helicus, an effective strain to degrade biphenyl, treated with higher copper level [20]. This showed the detoxification abilities of this fungus and the adaptation to heavy metals and biacrylic compounds. Bengtsson and co-workers studied uranium biosorption capacity of Talaromyces emersonii. The biomass had a relatively high biosorption capacity for the uranium with $280 \mathrm{mg} \mathrm{g}^{-1}$ dry weight. The maximum biosorption capacity was calculated through using Langmuir model with $323 \mathrm{mg}$ uranium $\mathrm{g}^{-1}$ dry weight biomass [21]. Furthermore, Talaromyces wortmannii and T. flavus, were obtained from sediments highly contaminated with arsenic $(1403 \mathrm{mg} \mathrm{L}$

${ }^{1}$ of arsenic). However, biovolatilization values of arsenic by Talaromyces wortmannii and T. flavus were insignificant [22]. Nevertheless, there is no study relating to metal or dye biosorption by Talaromyces aculeatus in the literature.

Thus, the major objective of this work was to detect the biosorption potentials of Reactive Blue 13, Reactive Blue 72, Reactive Yellow 85 and Reactive Orange 13 of a strain of Talaromayces aculeatus as low-cost adsorbent. Batch experiments were performed to test the impact of different experimental parameters onto biosorption for instance $\mathrm{pH}$, biosorbent dosage, time, temperature and initial dye concentration.

\section{EXPERIMENTAL}

\subsection{Chemical and Dyes}

Reactive dyestuffs such as Reactive Blue 72 (RB72), Reactive Blue 13 (RB13) $\left(\mathrm{C}_{29} \mathrm{H}_{14} \mathrm{ClN}_{7} \mathrm{O}_{14} \mathrm{~S}_{4}\right.$. Cu.4Na), Reactive Yellow 85 (RY85) $\left(\mathrm{C}_{27} \mathrm{H}_{22} \mathrm{Cl}_{2} \mathrm{~N}_{14} \mathrm{Na}_{2} \mathrm{O}_{9} \mathrm{~S}_{2}\right)$ and Reactive Orange 13 (RO13) $\left(\mathrm{C}_{24} \mathrm{H}_{15} \mathrm{ClN}_{7} \mathrm{Na}_{3} \mathrm{O}_{10} \mathrm{~S}_{3}\right)$ in commercial purity were ensured by Sarar Textile Company, Eskisehir, Turkey. All chemicals were purchased from Merck and Carlo Erba.

\subsection{Biosorbent Preparation}

Talaromyces aculeatus (AMDC-14) used as biosorbent had been isolated from acidic mine drainage (AMD) in Çan coal mine drainage (Çanakkale province, Turkey) having $\mathrm{pH} 2.81$ in our previous study (unpublished work). 
Talaromyces represent the teleomorphic state of ascomycetous fungi. The fungus was identified as Talaromyces aculeatus AMDC-14 with GenBank accession number KF588646 in our previous study (unpublished work). After this strain was grown on malt broth slants for 7 days at $25^{\circ} \mathrm{C}$, the obtained 1 $\mathrm{mL}$ of mycelium suspension was inoculated to malt broth. The flask was incubated at $30^{\circ} \mathrm{C}$ with 150 $\mathrm{rpm}$ for 7 days. The obtained biomasses were filtered and dried in an oven at $55{ }^{\circ} \mathrm{C}$. And then, the biomass was ground and sieved to $300 \mu \mathrm{m}$ and less particle size and used as biosorbent.

\subsection{Batch Biosorption Experiments}

Biosorption studies were performed in a batch system with a $100 \mathrm{~mL}$ flask including $50 \mathrm{~mL}$ of $50 \mathrm{ppm}$ dye solution. The impacts of the parameter to bioadsorption process were investigated: $\mathrm{pH}(1.0-7.0)$, agitation rate $(0-200 \mathrm{rpm})$, temperature $\left(25-40{ }^{\circ} \mathrm{C}\right)$, contact period $(0-1440 \mathrm{~min})$, biosorbent dose $(0.1-$ $\left.2.5 \mathrm{~g} \mathrm{~L}^{-1}\right)$. After the bioadsorption process, the samples were centrifuged at $9000 \mathrm{rpm}$ for 5 minutes and dye concentration which remaining after treatment was determined by UV-VIS spectrophotometer (Shimadzu UV-2550). Absorbances of dyes in solutions were measured spectrophotometrically at a wavelength of 487, 422, 628 and $568 \mathrm{~nm}$ for RO13, RY85, RB72, RB13, respectively. All the experiments were performed in double.

\subsection{Kinetic Studies}

The experiments were performed using $50 \mathrm{~mL}$ of $50 \mathrm{ppm}$ dye solution and $0.1 \mathrm{~g}$ of biosorbent at $\mathrm{pH} 2$ in $100 \mathrm{~mL}$ flask at $150 \mathrm{rpm}$ under controlled temperature. The samples were taken at various contact periods and the dye concentrations remained were analysed by UV-vis spectrophotometer. The studies were investigated for kinetic approach at three different temperatures 30,35 and $40{ }^{\circ} \mathrm{C}$.

\subsection{Equilibrium Studies}

To determine the equilibrium studies, experiments were carried out using different initial dye concentrations of (10-200 ppm) at $\mathrm{pH} 2,30{ }^{\circ} \mathrm{C}$ and optimal biosorbent dosages. The samples were agitated at $150 \mathrm{rpm}$ for $120 \mathrm{~min}$ of contact time and the dye concentration after treatment was measured.

\subsection{Characterization Studies}

In this study, the mechanism of the bioadsorption process was analysed with FTIR spectroscopy. The FTIR spectra of the biosorbent before and after biosorption were recorded utilizing spectrophotometer (Bruker Tensor 27) in the region of $400-4000 \mathrm{~cm}^{-1}$. Measurement was performed on $\mathrm{KBr}$ pellets prepared by pressing $1 \mathrm{mg}$ of dry powdered sample and $100 \mathrm{mg}$ of $\mathrm{KBr}$ (spectrometry grade) under vacuum. Moreover, scanning electron microscopy analysis using a JEOL 5600 LV SEM instrument was performed to define potential changes in the biosorbent particle surfaces.

\section{RESULTS AND DISCUSSION}

\subsection{Impact of $\mathbf{p H}$}

$\mathrm{pH}$ is an important parameter affecting biosorption capacity at aqueous medium. Therefore the $\mathrm{pH}$ effect on the dye removal yield and capacity was studied at various $\mathrm{pH}$ value between $1-7$. The results were presented in Figure 1. It has been revealed that $\mathrm{pH} 2$ was the best for removal for all dyes. $\mathrm{pH} 2$ led to proton coverage of binding regions of cell surface. For all textile dyes in this study, the biosorption percentages of fungal biosorbent decreased with enhancing $\mathrm{pH}$ (after $\mathrm{pH} 2$ ), indicating the important forces between dye anion molecules and the dye binding regions of the positively charged bioadsorbent surface. In other words, the negative charge density on the biosorbent surface enhanced when the $\mathrm{pH}$ was increased; therefore biosorption was decreased [17-19]. 
Katar et al. / Anadolu Univ. J. of Sci. and Technology A-Appl. Sci. and Eng. 18 (2) - 2017

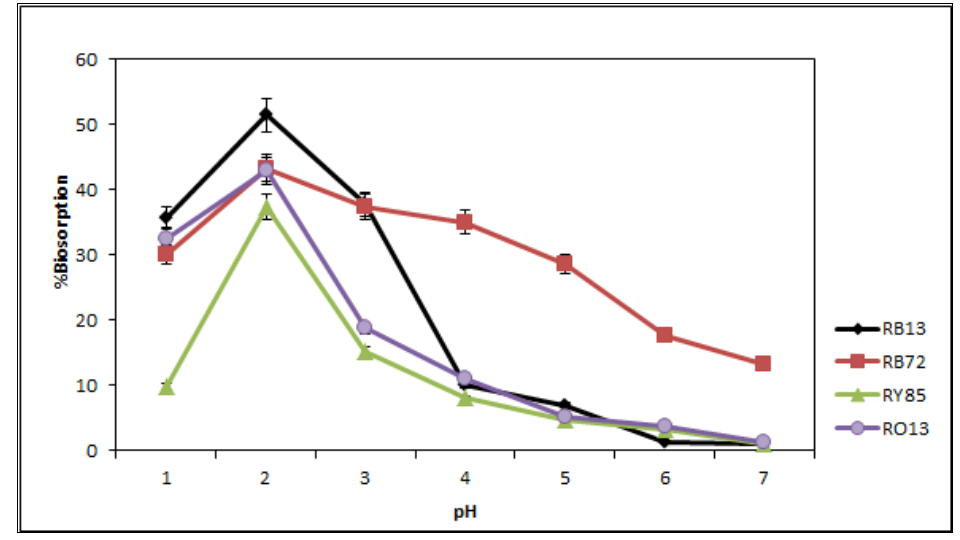

Figure 1. Effect of pH on biosorption of dyes a) RB13 b) RB72 c) RY85 d) RO13 (experimental conditions: Co:50 ppm; biosorbent dosage: $2 \mathrm{~g} \mathrm{~L}^{-1}$; temperature $30{ }^{\circ} \mathrm{C}$; agitation rate 150 rpm; time: $60 \mathrm{~min}$.)

\subsection{Impact of Biosorbent Dosage}

Dosage of biosorbent is a significant factor onto biosorption yield and capacity of dye adsorption to determine adsorbent-sorbate equilibrium of the system. The biosorbent dosage effect onto removal of dyes was evaluated at the range of 0.1-2.5 $\mathrm{g} \mathrm{L}^{-1}$ biomass. Dyes removal increased with the biosorbent dosage increasing for RB13, RY85 and RO13 dyes until $2 \mathrm{~g} \mathrm{~L}^{-1}$ with the value of 51.5\%, 37.41\% and $42.91 \%$, respectively. However, when $1.2 \mathrm{~g} \mathrm{~L}^{-1}$ of biosorbent dosage for RB72 was used, biosorption yield was 50.26 (Figure 2). A further increase did not show significant change for dyes uptake. Similar results were found in the literature [17]. Until dosage reaches a critical point, Enhancement of biosorption yield with biyosorbent dosage can be attributed to increase in non-living biomass surface and augmentation more adsorption sites requested for biosorption.

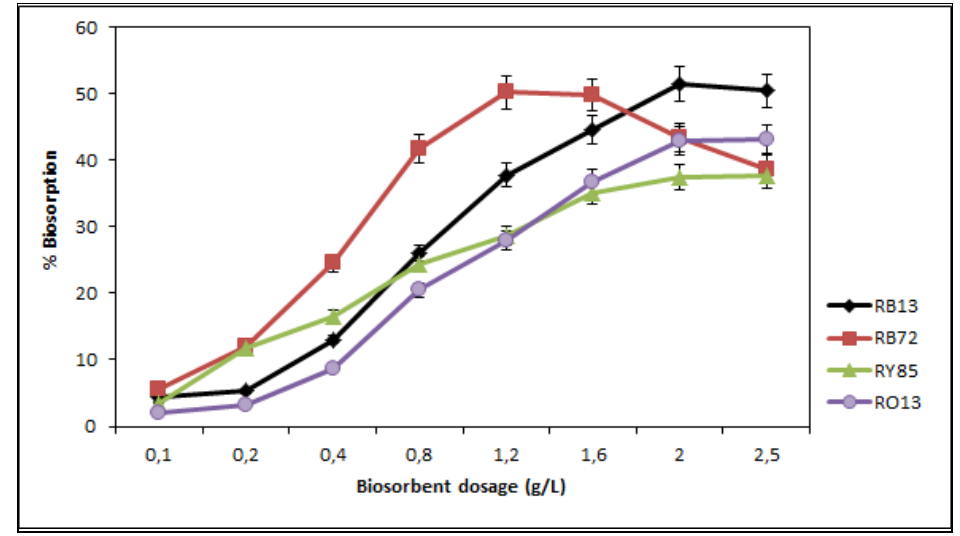

Figure 2. Effect of biosorbent dosage on biosorption of dyes a) RB13 b) RB72 c) RY85 d) RO13 (experimental conditions: $\mathrm{Co}: 50 \mathrm{ppm} ; \mathrm{pH} 2$; temperature $30^{\circ} \mathrm{C}$; agitation rate $150 \mathrm{rpm}$; time: 60 min.)

\subsection{Impact of Agitation Rate}

The biosorption of RB13, RB72, RY85 and RO13 increased when the agitation rate changing from 0$150 \mathrm{rpm}$ but no significant increase was shown range from 150 to $200 \mathrm{rpm}$. Thus the top removal yield reached at $150 \mathrm{rpm}$ so this optimum parameter was studied for the further experiments (Figure 3). In general, the enhancement of biosorption yield with increasing agitation rates up to $150 \mathrm{rpm}$ was attributed to an enhanced mass transfer rate [19]. 
Katar et al. / Anadolu Univ. J. of Sci. and Technology A-Appl. Sci. and Eng. 18 (2) - 2017

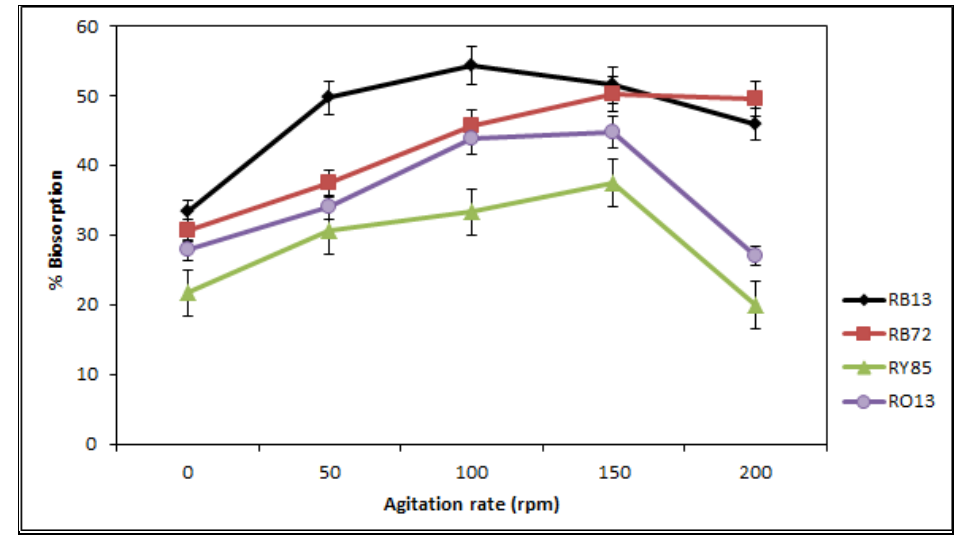

Figure 3. Effect of agitation rate on biosorption of dyes a) RB13 b) RB72 c) RY85 d) RO13 (experimental conditions: Co:50 ppm; $\mathrm{pH}$ 2; biosorbent dosage: $2 \mathrm{~g} \mathrm{~L}^{-1}$ [excluding RB72; 1.2 $\left.\mathrm{g} \mathrm{L}^{-1}\right]$; temperature $30^{\circ} \mathrm{C}$; time: $60 \mathrm{~min}$.)

\subsection{Impact of Temperature}

In order to examine the effect of temperature on biosorption capacity of Talaromyces aculeatus AMDC14 biomass for selected dyes experiments were carried out $25,30,35$ and $40{ }^{\circ} \mathrm{C}$. Results indicate that removal of dyes increased with increasing of temperature. Figure 4 showed that the capacity of the adsorption onto Talaromyces aculeatus AMDC-14 increased with a generally increasing in temperature from 25 to $40^{\circ} \mathrm{C}$. This result indicates that biosorptions of dyes are an endothermic except RB 72, which is further demonstrated in section 3.9. According to the study of Aytar and co-workers, the biosorption capacity of the biosorbent of $P$. ochrochloron AMDB-12 isolated from another metal mine drainage was similarly increased with an enhancement in temperature from 20 to $40^{\circ} \mathrm{C}$ [19].

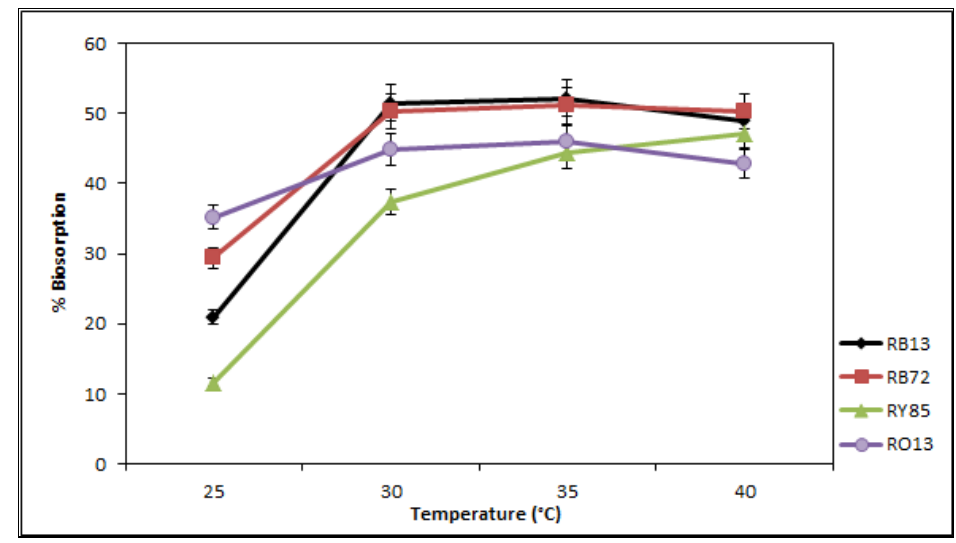

Figure 4. Effect of temperature on biosorption of dyes a) RB13 b) RB72 c) RY85 d) RO13 (experimental conditions: Co:50 ppm; $\mathrm{pH}$ 2; biosorbent dosage: $2 \mathrm{~g} \mathrm{~L}^{-1}$ [excluding RB72; $1.2 \mathrm{~g} \mathrm{~L}^{-1}$ ]; agitation rate: $150 \mathrm{rpm}$; time: $60 \mathrm{~min}$.)

\subsection{Impact of Contact Time}

Contact time effect of on bioadsorption was tested by using different contact times as shown in Figure 5 , the biosorption yield enhanced with enhancing contact period until $120 \mathrm{~min}$. After $120 \mathrm{~min}$, no major increases were observed; thereby, the equilibrium contact time was detected as $120 \mathrm{~min}$. It is possible that all biosorbent regions are empty at the initial time and higher dye concentration is gradient effect 
for bulk dye molecules transfer to other sites. The biosorption profile over time for all dyes reached a plateau after equilibrium; thereby indicating that a monolayer coating of dye may have been obtained on the Talaromyces aculeatus AMDC-14 surface at that time. It has been found that the bioadsorption generally occurs at early phase of contact periods owing to in abundance convenient active sites, and with the passage of time the process transfer rate slow owing to electrostatic repulse between biosorbed and unbiosorbed dyestuff molecules [23].

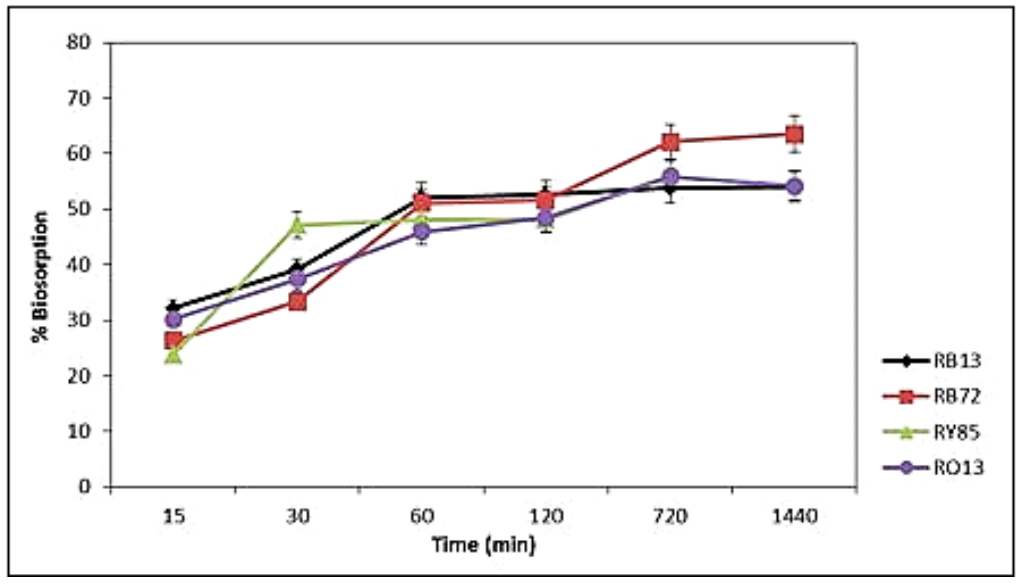

Figure 5. Effect of contact time on biosorption of dyes a) RB13 b) RB72 c) RY85 d) RO13 (experimental conditions: Co:50 ppm; $\mathrm{pH}$ 2; biosorbent dosage: $2 \mathrm{~g} \mathrm{~L}^{-1}$ [excluding RB72; $1.2 \mathrm{~g} \mathrm{~L}^{-1}$ ]; agitation rate: $150 \mathrm{rpm}$; temperature: $35^{\circ} \mathrm{C}$ [excluding $\mathrm{RY} 85,40{ }^{\circ} \mathrm{C}$ ).

\subsection{FTIR and SEM Analyses}

Functional groups on biosorbent surface are carboxyl, phosphate, hydroxyl, amino groups which are originated from the components of cell wall such as chitin, chitosan, glucan, phosphomannan [24]. Figure 6 indicated that the FTIR spectra of raw and dyes-loaded Talaromyces aculeatus AMDC-14 biosorbents were compared to acquire information on the biosorption of dyes onto the adsorbent. According to this figure, the changes at the peaks of biosorbents associated with adsorption were considered to reflect bioadsorption.

FTIR bands were observed at approximately $3400 \mathrm{~cm}^{-1}$ for both raw and dye-loaded biosorbents, which reflect the presence of $-\mathrm{OH}$ or $-\mathrm{NH}$ groups. Besides, the symmetrical and asymmetrical bands of $-\mathrm{CH}$ stretching for both raw and dye-loaded biosorbents can be shown in the range of $2924-2307 \mathrm{~cm}^{-1}$. AmidI band was seen at 1645 in the untreated biomass and $1647 \mathrm{~cm}^{-1}$ for all dye-loaded biomasses. 1492 $\mathrm{cm}^{-1}$ band of the unloaded biomass can be assigned to the amid-II band. This band shifted to $1490 \mathrm{~cm}^{-1}$ for all dye-loaded biosorbents. The band of $-\mathrm{CH}$ bending vibrations was $1383 \mathrm{~cm}^{-1}$ for raw biomass. There is no this band in all dye-loaded biomasses excluding RO13-loaded biomass. The bands at 1155, $1153,1153 \mathrm{~cm}^{-1}$ and $1151 \mathrm{~cm}^{-1}$ in the FTIR spectrum of dye-loaded biomasses (RB13, RB72, RY85, and RO13, respectively) are indicative of the presence of $-\mathrm{S}=\mathrm{O}$ stretching; but, this band was detected at $1190 \mathrm{~cm}^{-1}$ in the untreated biomass. Thereby, the observation of this band after dye bioadsorption may be attributed to stretching vibrations of sulfonate groups [25]. There was not any strong shifting in the absorption band at $1026 \mathrm{~cm}^{-1}$ between raw and dye-loaded biosorbents. Bands at $898-651 \mathrm{~cm}^{-1}$, which were attributed to the biosorption characteristics of aromatic groups, also indicated alterations in biosorption for each dyestuff. However, there is no peak referring aromatic group in the FTIR spectra of RB13-loaded biosorbent. To remove of acidic dyes from aqueous solutions, the electrostatic interactions were also proposed in this study as well as the studies of Colak and co-workers [26], Cengiz 
Katar et al. / Anadolu Univ. J. of Sci. and Technology A-Appl. Sci. and Eng. 18 (2) - 2017

et al. [27] and Çabuk et al. [18]. This may be explained by the electrostatic attraction between the positively charged surface $\left(\mathrm{NH}_{3}{ }^{+},-\mathrm{COOH}_{2}{ }^{+}\right)$and the negative sulfonate $\left(-\mathrm{SO}_{2} \mathrm{O}^{-}\right)$groups of the dyestuff molecule in acidic environment.

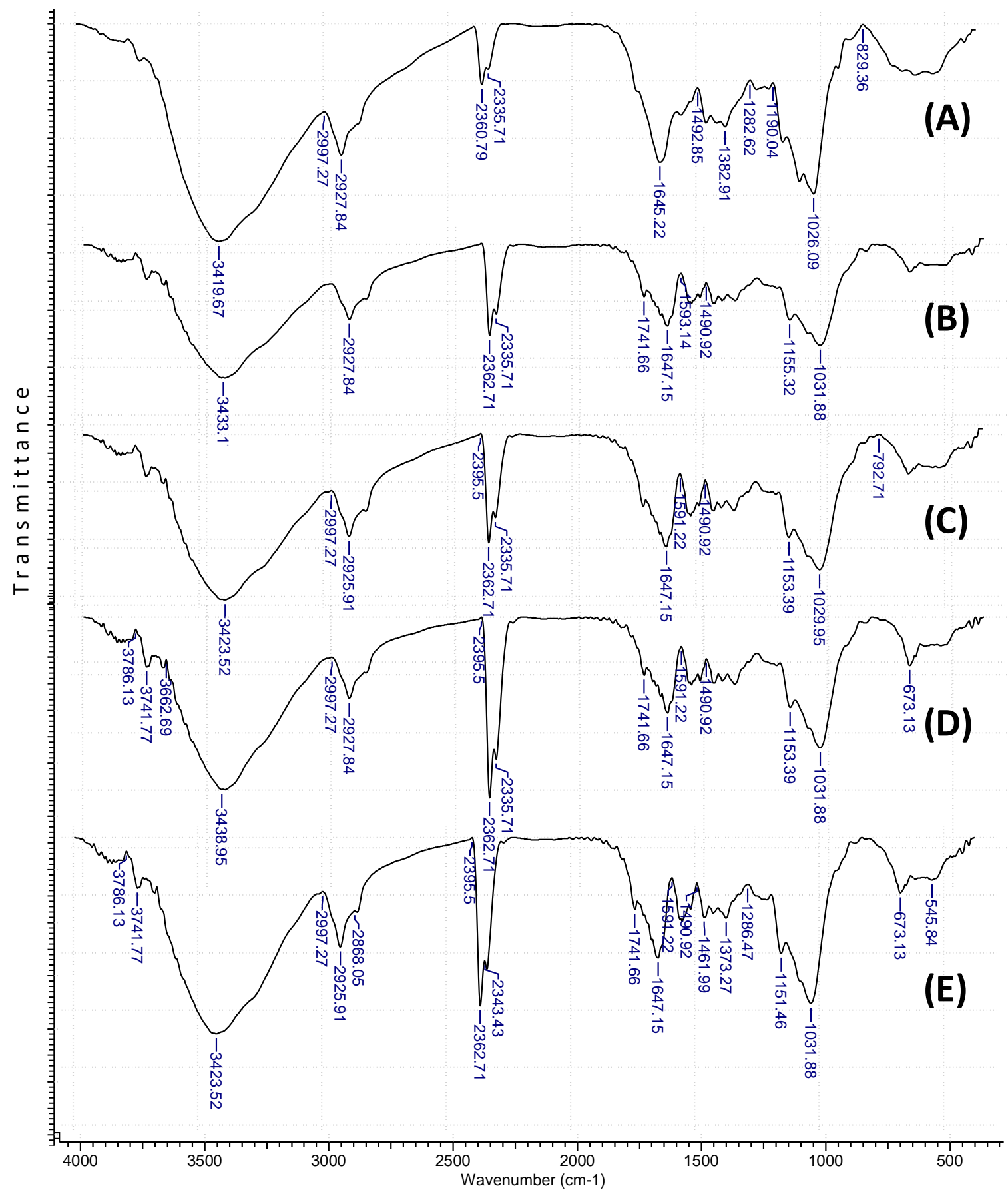

Figure 6. Infrared spectra of T. aculeatus biosorbent reacted with reactive dyes (A) Raw biosorbent (B) biosorbent loaded RB13 (C) biosorbent loaded RB72 (C) biosorbent loaded RY85 (D) biosorbent loaded RO13.

As shown in Figure 7, the SEM images of both raw biosorbent (Figure 7A) and dye-loaded biosorbents (7B-7E) were visualized. The surface of the fungus biomass was smooth and porous. 


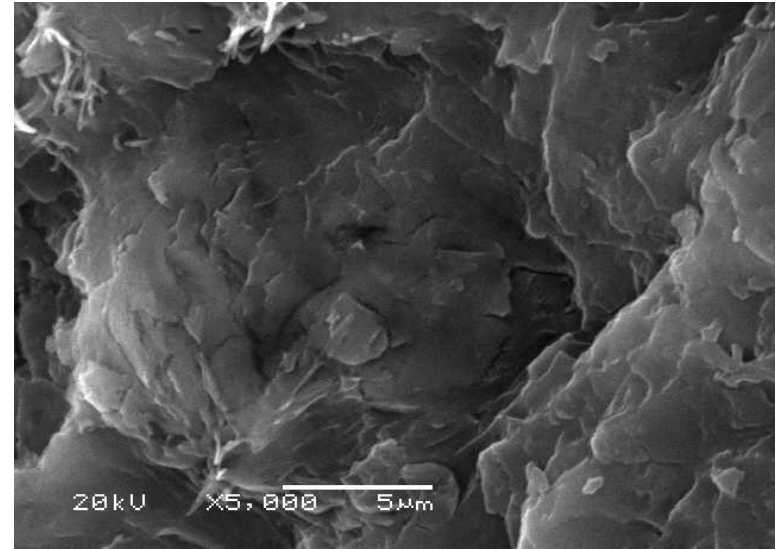

(A)

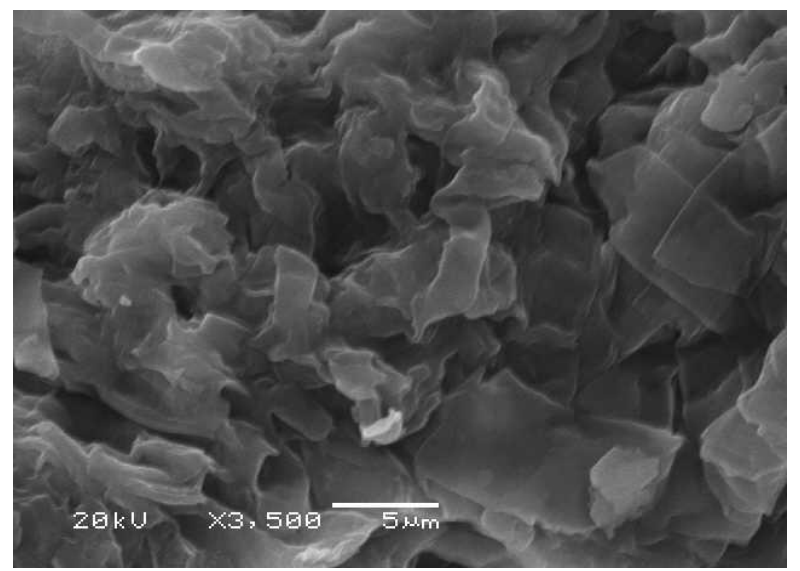

(C)

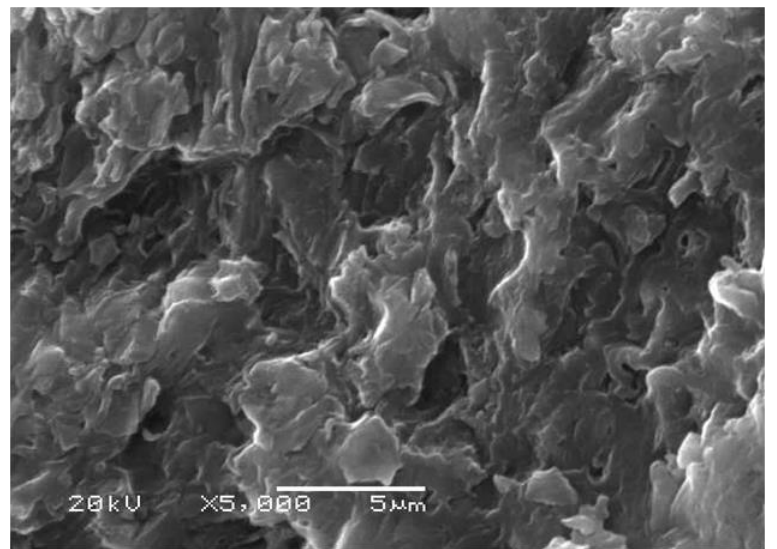

(B)

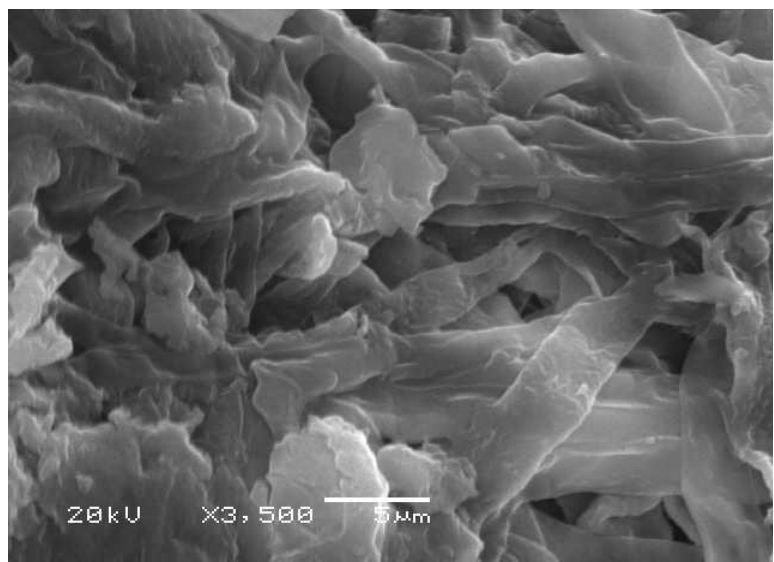

(D)

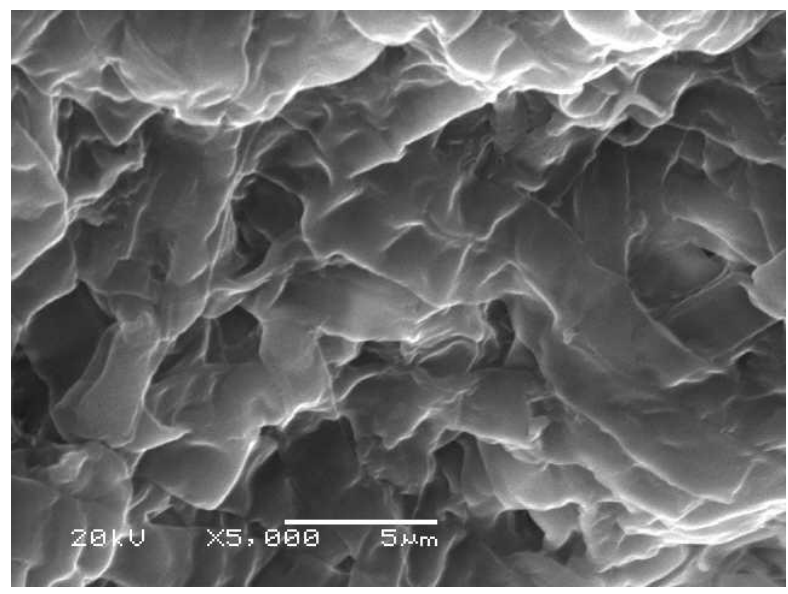

(E)

Figure 7. Scanning electron microscopy images of raw (A), and other biosorbents loaded RB13 (B), loaded RB72 (C), loaded RY85 (D), loaded RO13 (E).

The irregular and heterogeneous surface of the fungus provides a great surface area to the biosorbent, affecting the adsorbent capacity. The alterations in the morphologies of the dye-loaded biosorbents 
showed in Figure 7 (B-E) compared to that of Talaromyces aculeatus AMDC-14 in Figure 7 (A) reveals that the dye is biosorbed onto the biosorbent surface.

\subsection{Biosorption Kinetics}

Contact time effect onto biosorption of dyes at different temperatures was shown at Figure 5. At the initial time for three selected temperatures, efficient biosorption occurred and then the biosorption yield gradually reaches plateau after 120 minutes. For a practical application, rapidly biosorption is a significant in treatment of wastewater.

To investigate the kinetic result of biosorption process the experimental data were analysed by the Lagergren pseudo-first and pseudo-second order kinetic models.

The linear form of the Lagergren pseudo-first and pseudo-second order kinetic model can be defined as:

$$
\begin{aligned}
& \log \left(\mathrm{q}_{\mathrm{e}}-\mathrm{q}_{\mathrm{t}}\right)=\log \mathrm{q}_{\mathrm{e}}-\frac{\mathrm{k}_{1} \mathrm{t}}{2,303} \\
& \frac{\mathrm{t}}{\mathrm{q}_{\mathrm{t}}}=\frac{1}{\mathrm{k}_{2} \mathrm{qe}_{\mathrm{e}}^{2}}+\frac{\mathrm{t}}{\mathrm{q}_{\mathrm{e}}}
\end{aligned}
$$

where $\mathrm{k}_{1}\left(\mathrm{~min}^{-1}\right)$ is the pseudo-first-order rate constant, $\mathrm{q}_{\mathrm{e}}$ and $\mathrm{q}_{\mathrm{t}}$ are the amount of dye adsorbed (mg $\left.\mathrm{g}^{-1}\right)$ at time $\mathrm{t}$ and at equilibrium, respectively, and $\mathrm{k}_{2}\left(\mathrm{~g} \mathrm{mg}^{-1} \mathrm{~min}^{-1}\right)$ is the pseudo-second-order rate constant of biosorption [28].

The plots of $\log \left(\mathrm{q}_{\mathrm{e}}-\mathrm{q}_{\mathrm{t}}\right)$ versus $\mathrm{t}$ and $\mathrm{t} / \mathrm{q}_{\mathrm{t}}$ versus $\mathrm{t}$ obtained from these models were checked graphically. The experimental data for the selected dyes and biomass biosorption mechanism were better defined by the pseudo-second order model for all dyes which presented the higher correlation coefficients at the investigated temperatures (Table 1). The calculated $\mathrm{q}_{\mathrm{e}}$ values were fitted much better with the experimental $\mathrm{q}_{\mathrm{e}}$ values for pseudo-second order calculations than pseudo-first order calculations. The constant pseudo-second order rate values changed increasing the temperature as indicated Table 1.

Table 1. Kinetic parameters for the adsorption of the dyes on the biosorbent

\begin{tabular}{|l|l|l|l|l|l|l|l|}
\hline & \multicolumn{5}{l}{ Pseudo first order } & Pseudo second order \\
\hline $\mathrm{T}\left({ }^{\circ} \mathrm{C}\right)$ & $\begin{array}{l}\mathrm{q}_{\mathrm{exp}} \\
\left(\mathrm{mg} \mathrm{g}^{-1}\right)\end{array}$ & $\begin{array}{l}\mathrm{q}_{\mathrm{e}} \\
\left(\mathrm{mg} \mathrm{g}^{-1}\right)\end{array}$ & $\begin{array}{l}\mathrm{k}_{1} \\
\left(\mathrm{~min}^{-1}\right)\end{array}$ & $\mathrm{R}^{2}$ & $\begin{array}{l}\mathrm{q}_{\mathrm{e}} \\
\left(\mathrm{mg} \mathrm{g}^{-1}\right)\end{array}$ & $\begin{array}{l}\mathrm{k}_{2} \\
\left(\mathrm{~g} \mathrm{mg}^{-1} \mathrm{~min}^{-1}\right)\end{array}$ & $\mathrm{R}^{2}$ \\
\hline RB13 \\
\hline 30 & 16.90 & 11.15 & 0.015 & 0.871 & 16.23 & $2.92 \times 10^{-3}$ & 0.997 \\
\hline 35 & 15.10 & 9.95 & 0.018 & 0.887 & 15.08 & $3.71 \times 10^{-3}$ & 0.999 \\
\hline 40 & 13.11 & 4.50 & 0.032 & 0.796 & 13.07 & $6.89 \times 10^{-3}$ & 0.999 \\
\hline RB72 \\
\hline 30 & 23.13 & 18.81 & 0.012 & 0.925 & 22.62 & $2.37 \times 10^{-3}$ & 0.997 \\
\hline 35 & 25.87 & 20.69 & 0.014 & 0.950 & 25.45 & $1.46 \times 10^{-3}$ & 0.993 \\
\hline 40 & 17.21 & 10.57 & 0.017 & 0.803 & 16.78 & $2.20 \times 10^{-3}$ & 0.999 \\
\hline RY85 \\
\hline 30 & 13.91 & 12.29 & $2.93 \times 10^{-3}$ & 0.958 & 13.70 & 0.0171 & 0.999 \\
\hline 35 & 26.32 & 24.74 & $7.6 \times 10^{-3}$ & 0.980 & 26.04 & $4.28 \times 10^{-3}$ & 0.999 \\
\hline 40 & 28.86 & 26.63 & $8.52 \times 10^{-3}$ & 0.976 & 28.25 & $2.73 \times 10^{-3}$ & 0.999 \\
\hline RO13
\end{tabular}




\subsection{Equilibrium Isotherms}

The analysis of equilibrium data is significant for the improvement of mathematical models for using to determine the biosorption process. Different isotherm models such as Langmuir and Freundlich are used to define the biosorption isotherm. Following formulas are used as linear forms of the equations (Eqs. 3 and 4) $[29,30]$.

$$
\begin{aligned}
& \frac{\mathrm{C}_{\mathrm{e}}}{\mathrm{q}_{\mathrm{e}}}=\frac{1}{\mathrm{bq}_{0}}+\frac{\mathrm{C}_{\mathrm{e}}}{\mathrm{q}_{0}} \\
& \log \mathrm{q}_{\mathrm{e}}=\log \mathrm{K}_{\mathrm{f}}+\frac{1}{\mathrm{n}} \log \mathrm{C}_{\mathrm{e}}
\end{aligned}
$$

Constant of the models are $\mathrm{q}_{\mathrm{e}}$ [the amount of biosorbed dye per amount of adsorbent at equilibrium (mg $\left.\left.\mathrm{g}^{-1}\right)\right], \mathrm{C}_{\mathrm{e}}$ [the equilibrium concentration in the solution $\left(\mathrm{mg} \mathrm{L}^{-1}\right)$ ]. The Langmuir constants, $\mathrm{q}_{\mathrm{o}}\left(\mathrm{mg} \mathrm{g}^{-1}\right)$ and $\mathrm{b}\left(\mathrm{L} \mathrm{mg}^{-1}\right)$, represent the monolayer adsorption capacity and the adsorption equilibrium constants, respectively. $\mathrm{K}_{\mathrm{f}}$ and $\mathrm{n}$, the monolayer adsorption capacity and equilibrium constant of biosorption are Freundlich coefficients.

$$
\mathrm{R}_{\mathrm{L}}=\frac{1}{1+\mathrm{bC}_{0}}
$$

Where $C_{0}$ is the initial dye concentration $\left(\mathrm{mg} \mathrm{L}^{-1}\right) . R_{L}$ values calculated from the above equation are incorporated (Eq. 5).

The biosorption data from initial concentrations such as 10,50,100, and $200 \mathrm{ppm}$, were investigated at $\mathrm{pH} 2.0$ and temperatures of 30,35 and $40^{\circ} \mathrm{C}$.

The experimental data were analysed with two isotherm models and the isotherm coefficients and correlation coefficients are presented in Table 2. The high correlation coefficients lead the Langmuir model better fitted with equilibrium data. The Langmuir isotherm model is based on the biosorption occurs in monolayers at specific homogenous sites on the biosorbent. As the $\mathrm{R}_{\mathrm{L}}$ values lie between 0 and 1 , for all dyes at evaluated temperature are shown that adsorption process is favourable. The maximum adsorption capacities are calculated as 47.619, 243.91, 27.86 and 56.50 for RB13, RB72, RY85 and RO13 respectively. 
Katar et al. / Anadolu Univ. J. of Sci. and Technology A-Appl. Sci. and Eng. 18 (2) - 2017

Table 2. Isotherm used for the description of dyes adsorption on T. aculeatus cells and calculated adsorption and correlation coefficients

\begin{tabular}{|c|c|c|c|c|c|c|c|}
\hline \multicolumn{8}{|c|}{ RB13 isotherm data } \\
\hline $\mathrm{T}\left({ }^{\circ} \mathrm{C}\right)$ & \multicolumn{4}{|c|}{ Langmuir isotherm model } & \multicolumn{3}{|c|}{ Freundlich isotherm model } \\
\hline & $\begin{array}{l}\mathrm{q}_{0} \\
(\mathrm{mg} / \mathrm{g})\end{array}$ & $\begin{array}{l}\mathrm{b} \\
(\mathrm{L} / \mathrm{mg})\end{array}$ & $\mathrm{R}^{2}$ & $\mathrm{RL}_{(10-200)}$ & $\begin{array}{l}\mathrm{K}_{\mathrm{f}} \\
(\mathrm{mg} / \mathrm{g})(\mathrm{L} / \mathrm{mg}) 1 / \mathrm{n}\end{array}$ & $\mathrm{N}$ & $\mathrm{R}^{2}$ \\
\hline 30 & 47.62 & 0.0154 & 0.998 & $0.245-0.867$ & 1.207 & 1.432 & 0.9857 \\
\hline 35 & 47.39 & 0.0155 & 0.997 & $0.244-0.866$ & 1.256 & 1.447 & 0.9864 \\
\hline 40 & 41.49 & 0.0292 & 0.992 & $0.146-0.774$ & 1.867 & 1.576 & 0.9335 \\
\hline \multicolumn{8}{|c|}{ RB72 isotherm data } \\
\hline $\mathrm{T}\left({ }^{\circ} \mathrm{C}\right)$ & \multicolumn{4}{|c|}{ Langmuir isotherm model } & \multicolumn{3}{|c|}{ Freundlich isotherm model } \\
\hline & $\begin{array}{l}\mathrm{q}_{0} \\
(\mathrm{mg} / \mathrm{g})\end{array}$ & $\begin{array}{l}\mathrm{b} \\
(\mathrm{L} / \mathrm{mg})\end{array}$ & $\mathrm{R}^{2}$ & $\mathrm{RL}_{(10-200)}$ & $\begin{array}{l}\mathrm{K}_{\mathrm{f}} \\
(\mathrm{mg} / \mathrm{g})(\mathrm{L} / \mathrm{mg}) 1 / \mathrm{n}\end{array}$ & $\mathrm{N}$ & $\mathrm{R}^{2}$ \\
\hline 30 & 156.25 & 0.006 & 0.999 & $0.454-0.943$ & 1.251 & 1.187 & 0.996 \\
\hline 35 & 232.56 & 0.004 & 0.999 & $0.554-0.961$ & 1.127 & 1.118 & 0.997 \\
\hline 40 & 243.91 & 0.004 & 0.999 & $0.557-0.961$ & 1.165 & 1.115 & 0.998 \\
\hline \multicolumn{8}{|c|}{ RY85 isotherm data } \\
\hline $\mathrm{T}\left({ }^{\circ} \mathrm{C}\right)$ & \multicolumn{4}{|c|}{ Langmuir isotherm model } & \multicolumn{3}{|c|}{ Freundlich isotherm model } \\
\hline & $\begin{array}{l}\mathrm{q}_{0} \\
(\mathrm{mg} / \mathrm{g})\end{array}$ & $\begin{array}{l}\mathrm{b} \\
(\mathrm{L} / \mathrm{mg})\end{array}$ & $\mathrm{R}^{2}$ & $\mathrm{RL}_{(10-200)}$ & $\begin{array}{l}\mathrm{K}_{\mathrm{f}} \\
(\mathrm{mg} / \mathrm{g})(\mathrm{L} / \mathrm{mg}) 1 / \mathrm{n}\end{array}$ & $\mathrm{N}$ & $\mathrm{R}^{2}$ \\
\hline 30 & 27.86 & 0.0152 & 0.999 & $0.248-0.868$ & 0.742 & 1.472 & 0.972 \\
\hline 35 & 26.46 & 0.0201 & 0.991 & $0.199-0.833$ & 0.962 & 1.572 & 0966 \\
\hline 40 & 25.71 & 0.0278 & 0.997 & $0.152-0.783$ & 1.281 & 1.685 & 0.937 \\
\hline \multicolumn{8}{|c|}{ RO13 isotherm data } \\
\hline $\mathrm{T}\left({ }^{\circ} \mathrm{C}\right)$ & \multicolumn{4}{|c|}{ Langmuir isotherm model } & \multicolumn{3}{|c|}{ Freundlich isotherm model } \\
\hline & $\begin{array}{l}\mathrm{q}_{0} \\
(\mathrm{mg} / \mathrm{g})\end{array}$ & $\begin{array}{l}\mathrm{b} \\
(\mathrm{L} / \mathrm{mg})\end{array}$ & $\mathrm{R}^{2}$ & $\mathrm{RL}_{(10-200)}$ & $\begin{array}{l}\mathrm{K}_{\mathrm{f}} \\
(\mathrm{mg} / \mathrm{g})(\mathrm{L} / \mathrm{mg}) 1 / \mathrm{n}\end{array}$ & $\mathrm{N}$ & $\mathrm{R}^{2}$ \\
\hline 30 & 56.50 & 0.0088 & 0.999 & $0.363-0.919$ & 0.722 & 1.270 & 0.987 \\
\hline 35 & 51.81 & 0.0108 & 0.995 & $0.316-0.903$ & 0.883 & 1.339 & 0.988 \\
\hline 40 & 50.76 & 0.0141 & 0.990 & $0.262-0.876$ & 1.084 & 1.367 & 0.970 \\
\hline
\end{tabular}

\subsection{Thermodynamic Study}

Thermodynamic factors were analysed to understand the impacts of temperature and to define the feasibility of the biosorption process. The alterations in free energy $\left(\Delta \mathrm{G}^{\circ}\right)$, enthalpy $\left(\Delta \mathrm{H}^{\circ}\right)$, and entropy $\left(\Delta \mathrm{S}^{\circ}\right)$ of the biosorption process were calculated utilizing the Langmuir equilibrium constants (b) (Eqs. 6 and 7$)$ :

$$
\begin{aligned}
\operatorname{lnb} & =\frac{\Delta S^{0}}{R}-\frac{\Delta H^{0}}{R}\left(\frac{1}{T}\right) \\
\Delta G^{0} & =\Delta H^{0}-T \Delta S^{0}
\end{aligned}
$$

where $\mathrm{R}$ is the gas constant $\left(8.314 \mathrm{~J} \mathrm{~mol}^{-1}\right)$ and $\mathrm{T}$ is the solution temperature $(\mathrm{K})$. The value of $\Delta \mathrm{H}^{\mathrm{o}}$ is calculated from the slope of the equation. $\Delta \mathrm{S}^{0}$ is obtained from the intercept of the equation of the plotted data and $\Delta \mathrm{G}^{\mathrm{o}}$ was calculated by using these values.

The negative values of $\left(\Delta \mathrm{G}^{\circ}\right)$ demonstrated that the biosorptions of RY85, RO13, RB13 and RB72 by Talaromyces aculeatus AMDC-14 are spontaneous processes for the studied temperature range (Table $3)$. The degree of spontaneity enhanced with enhancing temperature for all dyes. 
The changes in the standard enthalpy $\Delta \mathrm{H}^{\circ}$ were $51.41 \mathrm{~J} \mathrm{~mol}^{-1},-37.20 \mathrm{~J} \mathrm{~mol}^{-1}, 47.83 \mathrm{~J} \mathrm{~mol}^{-1}$ and $37.85 \mathrm{~J}$ $\mathrm{mol}^{-1}$ for RB13, RB72, RY85 and RO13 respectively. This situation indicates that biosorptions of dyes are endothermic except RB 72. The positive values of $\Delta \mathrm{S}^{\circ}$ which calculated as $248.98 \mathrm{~J} \mathrm{~mol}^{-1} \mathrm{~K}^{-1}, 236.68$ $\mathrm{J} \mathrm{mol}^{-1} \mathrm{~K}^{-1}, 197.11 \mathrm{~J} \mathrm{~mol}^{-1} \mathrm{~K}^{-1}$ for RB13, RY85 and RO13 biosorption respectively suggest that the randomness at the adsorbent/solution interface enhances during the biosorption process of dyes onto Talaromyces aculeatus AMDC-14 biomass. However the $\Delta \mathrm{S}^{\circ}$ value of RB72 was found as $-33.03 \mathrm{~J} \mathrm{~mol}^{-}$ ${ }^{1} \mathrm{~K}^{-1}$ and this negative value showed a decrease in the degree of randomness.

Table 3. Thermodynamic parameters for the adsorption of the dyes on the biosorbent

\begin{tabular}{|c|c|c|c|}
\hline \multicolumn{4}{|c|}{ RB13 thermodynamic data } \\
\hline $\begin{array}{r}\text { Temperature } \\
\left({ }^{\circ} \mathrm{C}\right) \\
\end{array}$ & $\begin{array}{l}\Delta \mathrm{G}^{\circ} \\
\left(\mathrm{kJ} \mathrm{mol}^{-1}\right)\end{array}$ & $\begin{array}{l}\Delta \mathrm{H}^{\circ} \\
\left(\mathrm{J} \mathrm{mol}^{-1}\right)\end{array}$ & $\begin{array}{l}\Delta \mathrm{S}^{\circ} \\
\left(\mathrm{J} \mathrm{mol} \mathrm{K}^{-1}\right)\end{array}$ \\
\hline 30 & -75.39 & \multirow{3}{*}{51.41} & \multirow{3}{*}{248.98} \\
\hline 35 & -76.63 & & \\
\hline 40 & -77.88 & & \\
\hline \multicolumn{4}{|c|}{ RB72 thermodynamic data } \\
\hline $\begin{array}{r}\text { Temperature } \\
\left({ }^{\circ} \mathrm{C}\right)\end{array}$ & $\begin{array}{l}\Delta \mathrm{G}^{\circ} \\
\left(\mathrm{kJ} \mathrm{mol}^{-1}\right)\end{array}$ & $\begin{array}{l}\Delta \mathrm{H}^{\circ} \\
\left(\mathrm{J} \mathrm{mol}^{-1}\right)\end{array}$ & $\begin{array}{l}\Delta \mathrm{S}^{\circ} \\
\left(\mathrm{J} \mathrm{mol} \mathrm{K}^{-1}\right)\end{array}$ \\
\hline 30 & -0.032 & \multirow{3}{*}{-32.20} & \multirow{3}{*}{-33.031} \\
\hline 35 & -0.0322 & & \\
\hline 40 & -0.0322 & & \\
\hline \multicolumn{4}{|c|}{ RY85 thermodynamic data } \\
\hline $\begin{array}{r}\text { Temperature } \\
\left({ }^{\circ} \mathrm{C}\right) \\
\end{array}$ & $\begin{array}{l}\Delta \mathrm{G}^{\circ} \\
\left(\mathrm{kJ} \mathrm{mol}^{-1}\right)\end{array}$ & $\begin{array}{l}\Delta \mathrm{H}^{\circ} \\
\left(\mathrm{J} \mathrm{mol}^{-1}\right)\end{array}$ & $\begin{array}{l}\Delta \mathrm{S}^{\circ} \\
\left(\mathrm{J} \mathrm{mol} \mathrm{K}^{-1}\right)\end{array}$ \\
\hline 30 & -71.67 & \multirow{3}{*}{47.83} & \multirow{3}{*}{236.68} \\
\hline 35 & -72.85 & & \\
\hline 40 & -74.03 & & \\
\hline \multicolumn{4}{|c|}{ RO13 thermodynamic data } \\
\hline $\begin{array}{r}\text { Temperature } \\
\left({ }^{\circ} \mathrm{C}\right) \\
\end{array}$ & $\begin{array}{l}\Delta \mathrm{G}^{\circ} \\
\left(\mathrm{kJ} \mathrm{mol}^{-1}\right)\end{array}$ & $\begin{array}{l}\Delta \mathrm{H}^{\circ} \\
\left(\mathrm{J} \mathrm{mol}^{-1}\right)\end{array}$ & $\begin{array}{l}\Delta \mathrm{S}^{\circ} \\
\left(\mathrm{J} \mathrm{mol} \mathrm{K}^{-1}\right)\end{array}$ \\
\hline 30 & -59.69 & \multirow{3}{*}{37.55} & \multirow{3}{*}{197.11} \\
\hline 35 & -60.67 & & \\
\hline 40 & -61.66 & & \\
\hline
\end{tabular}

\section{CONCLUSION}

This study showed that non-living biomass Talaromayces aculeatus AMDC-14 is an effective biosorbent for removal of textile dyes (RB13, RB72, RY85 and RO13) from aqueous solutions. Biosorption efficiency of biomass was affected by experimental conditions such as biosorbent dosage, initial dye concentration, $\mathrm{pH}$, contact time and temperature. Efficiency of dye removal declined with increasing initial dye concentration for all investigated dyes in this study. But it increased with increasing temperature, biosorbent dosage and contact time. Maximum biosorption was found at $\mathrm{pH} 2$. Kinetic data were fitted into pseudo-second order kinetic model for all dyes and Langmuir isotherm model was best fit to the experimental equilibrium data, indicating monolayer sorption and homogenous surface of biosorbent. The maximum monolayer capacities were found for dyes RB13, RB72 and RO13 as $32.10,71.30$, and $31.30 \mathrm{mg} \mathrm{g}^{-1}$ at $308 \mathrm{~K}$ respectively and $20.67 \mathrm{mg} \mathrm{g}^{-1}$ for RY85 at $313 \mathrm{~K}$.

\section{ACKNOWLEDGEMENTS}

This study is based partly on the MSc thesis of S.Katar. 


\section{REFERENCES}

[1] Banat IM, Nigam P, Singh D, Marchant R. Microbial decolorization of textile-dye containing effluents: a review. Bioresource Technol 1996; 58: 217-227.

[2] Robinson T, McMullan G, Marchant R, Nigam P. Remediation of dyes in textile effluent: a critical review on current treatment technologies with a proposed alternative. Bioresource Technol 2001; 77: $247-255$.

[3] Pearce CI, Lloyd JR, Guthrie JT, The removal of colour from textile wastewater using whole bacterial cells: A review. Dyes Pigments 2003; 58: 179-196.

[4] Vandevivere PC, Bianchi R, Verstraete W. Treatment and reuse of wastewater from the textile wetprocessing industry: Emerging Technologies, J Chem Technol Biotechnol 1998; 72: 289-302.

[5] Sun Q, Yang L. The adsorption of basic dyes from aqueous solution on modified peat- resin particle. Water Res 2003; 37: 1535 -1544.

[6] Chowdhury S, Saha PD. Biosorption kinetics, thermodynamics and isosteric heat of sorption of $\mathrm{Cu}$ (II) onto Tamarindus indica seed powder. Colloids Surf B Biointerfaces 2011; 88: 697-705.

[7] Farooq U, Kozinski JA, Khan MA, Athar M. Biosorption of heavy metal ions using wheat based biosorbents-a review of the recent literature. Bioresorce Technol 2010; 101: 5043-5053.

[8] Elangovan R, Philip L, Chandraraj K. Biosorption of chromium species by aquatic weeds: kinetics and mechanism studies. J Hazard Mater 2008; 152:100-112

[9] Kang SY, Lee JU, Kim KW. Biosorption of Cr(III) and Cr(VI) onto the cell surface of Pseudomonas aeruginosa. Biochem Eng J 2007; 36: 54-58.

[10] Sandana Mala JG, Unni Nair B, Puvanakrishnan R. Bioaccumulation and biosorption of chromium by Aspergillus niger MTCC 2594. J Gen Appl Microbiol 2006; 52: 179-186.

[11] Volesky B. Biosorption and me. Water Res 2007; 41: 4017-4029

[12] Ramrakhiani L, Majumder R, Khowela S. Removal of hexavalent chromium by heat inactivated fungal biomass of Termitomyces clypeatus: surface characterization and mechanism of biosorption. Chem Eng J 2011; 171: 1060-1068

[13] López-Archilla AI, González AE, Terrón MC, Amils R. Ecological study of the fungal populations of the acidic Tinto River in southwestern Spain. Can J Microbiol 2004; 50: 923-934.

[14] Okparanma R, Ayotamuno MJ. Predicting chromium (VI) adsorption rate in the treatment of liquidphase oil-based drill cuttings. Afr J Environ Sci Technol 2008; 2: 68-74.

[15] McHale AP, Morrison J. Cellulase production during growth of Talaromyces emersonii CBS 814.70 on lactose containing media. Enzyme Microb Technol 1986; 8: 749-754.

[16] Bunni L, McHale L, McHale AP. Production, isolation and partial characterization of an amylase system produced by Talaromyces emersonii CBS 814.70. Enzyme Microb Technol 1989; 11: 370-375. 
Katar et al. / Anadolu Univ. J. of Sci. and Technology A-Appl. Sci. and Eng. 18 (2) - 2017

[17] Bireller ES, Aytar P, Gedikli S, Cabuk A. Removal of some reactive dyes by untreated and pretreated Saccharomyces cerevisiae, alcohol fermentation waste, J Sci Ind Res 2012; 710: 632-639.

[18] Cabuk A, Aytar P, Gedikli S, Ozel YK, Kocabiyik E. Biosorption of acidic textile dyestuffs from aqueous solution by Paecilomyces sp. isolated from acidic mine drainage. Environ Sci Pollut Res 2013; 20: $4540-4550$.

[19] Aytar P, Bozkurt D, Erol S, Özdemir M, Çabuk A. Increased removal of Reactive Blue 72 and 13 acidic textile dyes by Penicillium ochrochloron fungus isolated from acidic mine drainage. Desalin Water Treat 2015; 1-11.

[20] Romero MC, Reinoso EH, Urrutia MI, Kiernan AM. Biosorption of heavy metals by Talaromyces helicus: a trained fungus for copper and biphenyl detoxification. Elect J Biotechnol 2006; 9: 1-11.

[21] Bengtsson L, Johansson B, Hackett TJ, McHale L, Mchale AP. Studies on the biosorption of uranium by Talaromyces emersonii CBS 814.70 biomass. Appl Microbiol Biotechnol 1995; 42: 807811.

[22] Cernansky S, Urik M, Sevc J, Khun M. Biosorption and Biovolatilization of Arsenic by HeatResistant Fungi. Env Sci Pollut Res 2007; 14: 31 - 35.

[23] Silva MDS, Cocenzo DS, Grillo R, Melo NFSD, Tonello PS, Oliveira LCD, Cassimiro DL, Rosa AH, Fraceto LF. Paraquat-loaded alginate/chitosan nanoparticles: Preparation, characterization and soil sorption studies. J Hazard Mater 2011; 19: 366-374.

[24] Yu J, Chi R, He Z, Qi Y, Zhan G. Combination of biosorption and photodegradation to remove methyl orange from aqueous solutions. Eng Life Sci 2011; 11: 309-315.

[25] Pacchade K, Sandhya S, Swaminathan K. Ozonation of reactive dye, Procion Red MX-5B catalyzed by metal ions. J Hazard Mater 2009; 167: 313-318.

[26] Colak F, Atar N, Olgun A. Biosorption of acidic dyes from aqueous solution by Paenibacillus macerans: kinetic, thermodynamic and equilibrium studies. Chem Eng J 2009; 150: 122-130.

[27] Cengiz G, Aytar P, Şam M, Çabuk A. Removal of reactive dyes using magnetically separable Trametes versicolor cells as a new composite biosorbent. Sep Sci Technol 2014; 1860-1871.

[28] Ho YS, McKay G. Pseudo-second order model for sorption processes. Proc Biochem 1999; 34: 451 465.

[29] Freundlich H. Kolloidchemie. Akademischer Verlagsgeselschaft, Leipzig, 1999.

[30] Langmuir I, The adsorption of gases on plane surfaces of glass, mica and platinum. J Am Chem Soc 1918; 40: 1361-1403. 